\title{
GIANT CELL TUMOUR OF BONE - A RARE SITE WITH RECURRENCE
}

\author{
Anupam Saha1, Mala Mukherjee ${ }^{2}$
}

1 Professor, Department of Pathology, MGM Medical College \& LSK Hospital, Kishanganj, Bihar.

${ }^{2}$ Assistant Professor, Department of Pathology, MGM Medical College \& LSK Hospital, Kishanganj, Bihar.

ABSTRACT

\section{BACKGROUND}

Occurrence of Giant cell tumour of bone (GCT) in phalanx of a finger is very rare. We here report a case of Giant cell tumour of middle phalanx of right ring finger in an 18 years-old female with evidence of recurrence after primary treatment and subsequent management. During clinical and radiological evaluation one should give proper importance to the fact that giant cell tumour can occur in extremely rare location and it has aggressive behaviour and potential of local recurrence.

\section{KEYWORDS}

Giant Cell Tumour, Middle Phalanx, Recurrence.

HOW TO CITE THIS ARTICLE: Saha A, Mukherjee M. Giant cell tumour of bone- a rare site with recurrence. J. Evolution Med. Dent. Sci. 2016;5(100): 7394-7396, DOI: 10.14260/jemds/2016/1673

BACKGROUND
Giant cell tumour (GCT) of bone usually occurs in epiphysis of long bones like distal femur, proximal tibia and distal radius etc. 1,2,3 However, it is extremely rare in phalanx of finger. The incidence of GCT in hand (including phalanges and metacarpals) is ranging from $1.7 \%$ to $2 \%$. Though most cases of GCT in these sites are benign, it shows high recurrence rate 4,5 with local aggressiveness after simple curettage and often needs en block excision. ${ }^{4}$ The recurrence of GCT of hand, especially of phalanx is significantly higher than that of other location. In $90 \%$ of cases, the local recurrence has been reported after curettage and bone grafting.4,67,8,9 Even after wide resection and reconstruction with structural bone grafting, high local recurrence rate is noted.4,5 Multiple surgical procedures like local and wide excision and amputation including ray amputation are used to cure the disease completely.

Here, we report a case of GCT of middle phalanx of right ring finger due to its rare location as well as local recurrence after 10 months of primary curettage and bone grafting. The recurrence of tumour was treated by amputation of affected phalanx, iliac crest bone grafting and arthrodesis.

\section{CASE REPORT}

An 18 years old female attended our institution reporting a history of trivial accident in December 2009 following which she had pain and soft tissue swelling of middle phalanx of right ring finger. As per advice of orthopaedic surgeon, digital x-ray was done. Radiological evaluation revealed aneurysmal bone cyst with the description of expansile subarticular osteolytic lesion of middle phalanx of right ring finger. [Figure - 1].

Financial or Other, Competing Interest: None.

Submission 09-11-2016, Peer Review 01-12-2016,

Acceptance 09-12-2016, Published 15-12-2016.

Corresponding Author:

Dr. Anupam Saha

Professor,

Department of Pathology,

MGM Medical College \& LSK Hospital,

Kishanganj-855107, Bihar.

E-mail: dranupamsaha@yahoo.co.in

DOI: $10.14260 /$ jemds $/ 2016 / 1673$
Just after one and half month she underwent curettage of lesion and bone graft. Tissue from lesion sent for histopathological examination.

Microscopical examination showed classical features of Giant cell tumour of bone with round or oval mononuclear stromal cells interspersed with many multinucleated osteoclastic type of giant cells. [Figure-2]. After 10 months of surgery, she again noticed pain and soft tissue swelling of that area. She underwent repeat digital x-ray along with MRI and spiral CT scan. All the investigations were suggestive of Giant cell tumour of bone. [Figure-3, 4, 5]. Bone scan was done. No other lesion detected. Ultimately, excision of middle phalanx of right ring finger was done along with iliac crest bone grafting and arthrodesis of Proximal Interphalangeal (PIP) and Distal Interphalangeal (DIP) Joint (Performed elsewhere). Bone graft stabilised proximally with two wires at right angles and distally with stainless wire and $\mathrm{K}$ wire (four stairs technique) in functional position. [Figure-6]. Histopathological examination of amputated middle phalanx proved the recurrence of Giant cell tumour. [Figure-7].

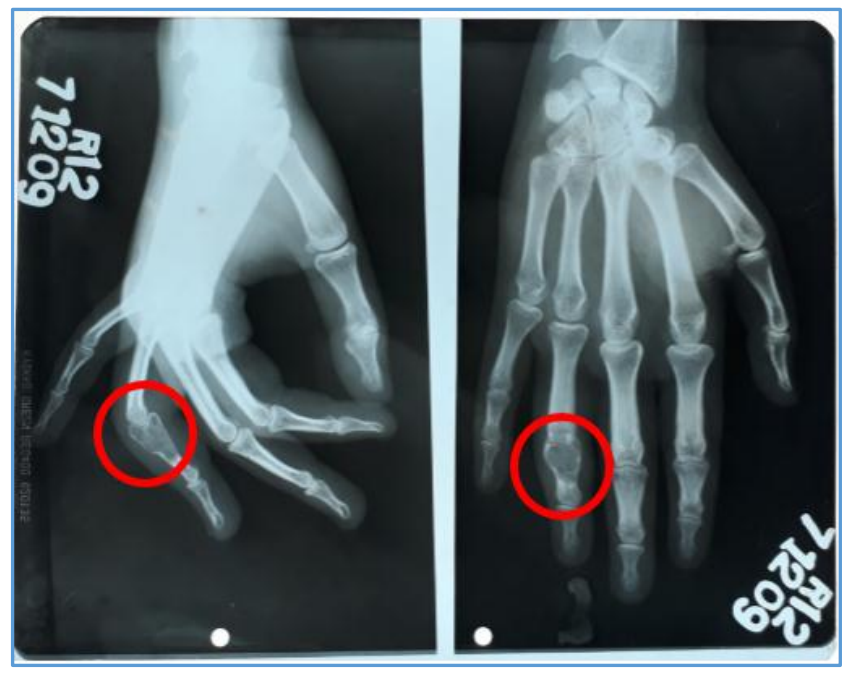

Figure 1. Report of first X-ray: Aneurysmal bone cyst of middle phalanx of right ring finger 


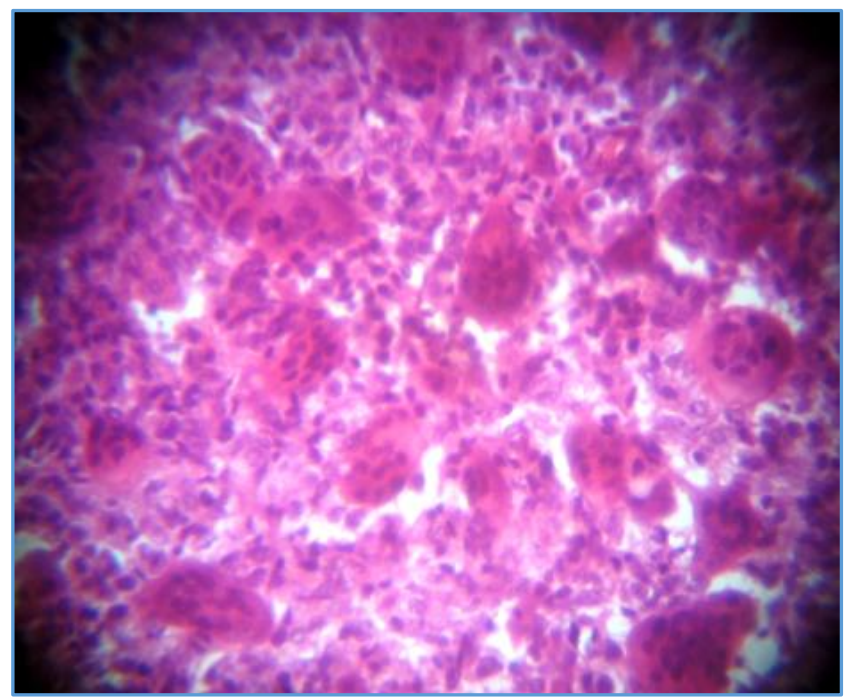

Figure 2. Histopathological diagnosis: Giant Cell Tumour of Bone

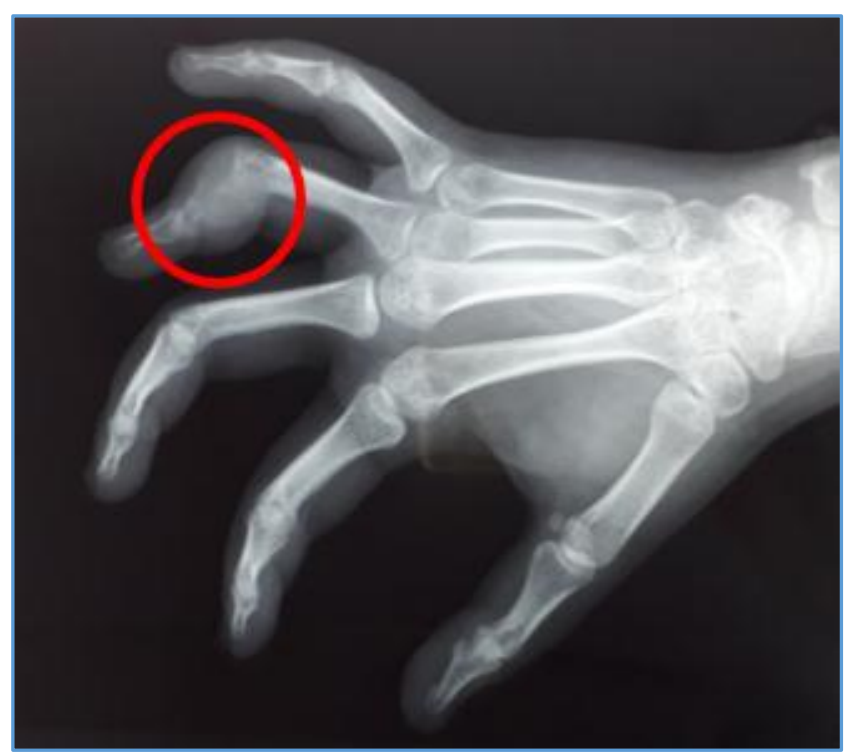

Figure 3. X-ray-suggestive of local recurrence of giant cell tumour of bone

of middle phalanx of right ring finger

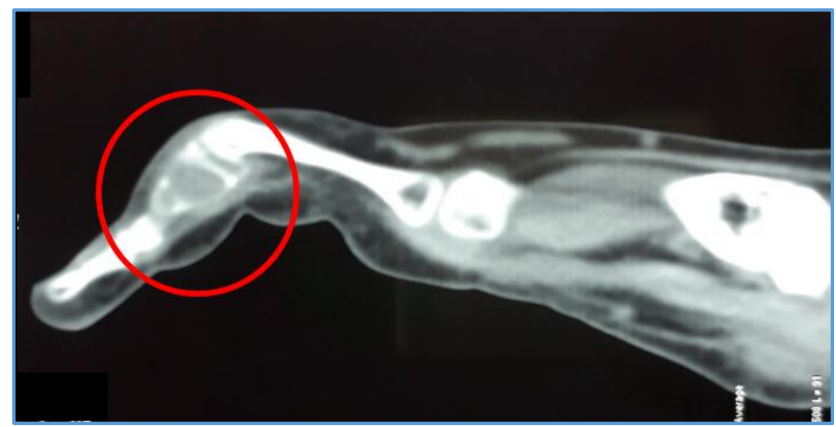

Figure 4. MRI scan suggested local recurrence of GCT of Bone of middle phalanx of right ring finger

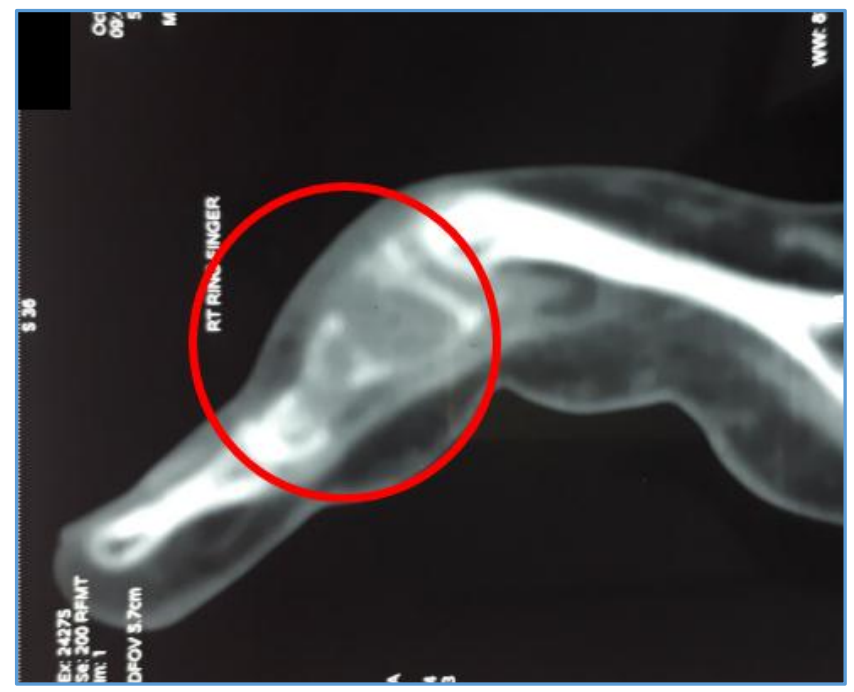

Figure 5. Spiral CT Scan: Suggestive of recurrence of GCT

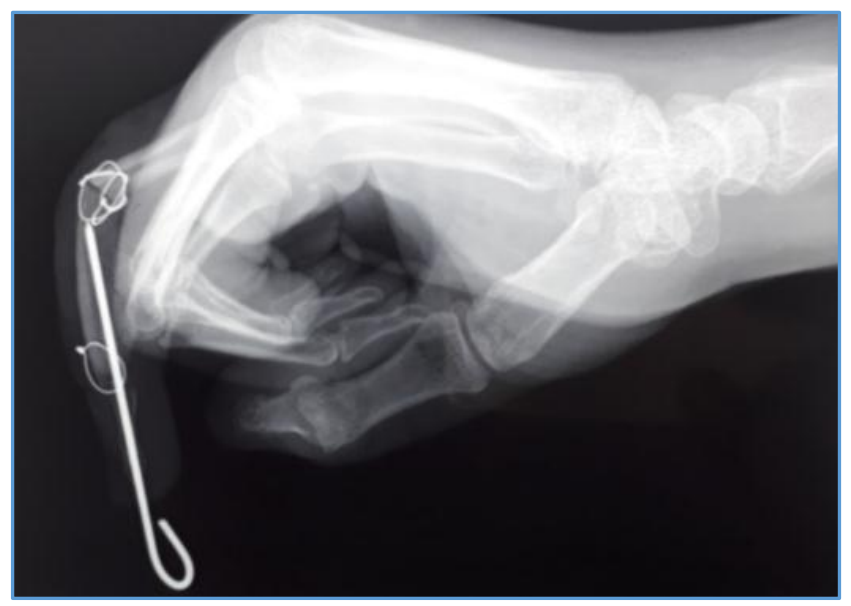

Figure 6. X-ray shows bone grafting and arthrodesis of Proximal Interphalangeal (PIP) and Distal

Interphalangeal (DIP) Joint after excision of affected middle phalanx of right ring finger

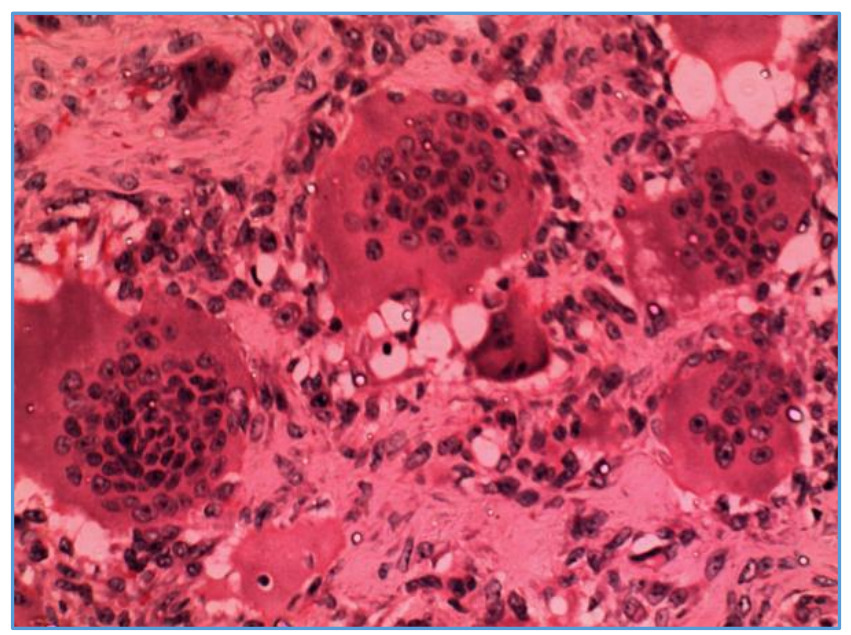

Figure 7. Microscopic features of recurrent Giant Cell Tumour of Bone in excised middle phalanx of right ring finger 


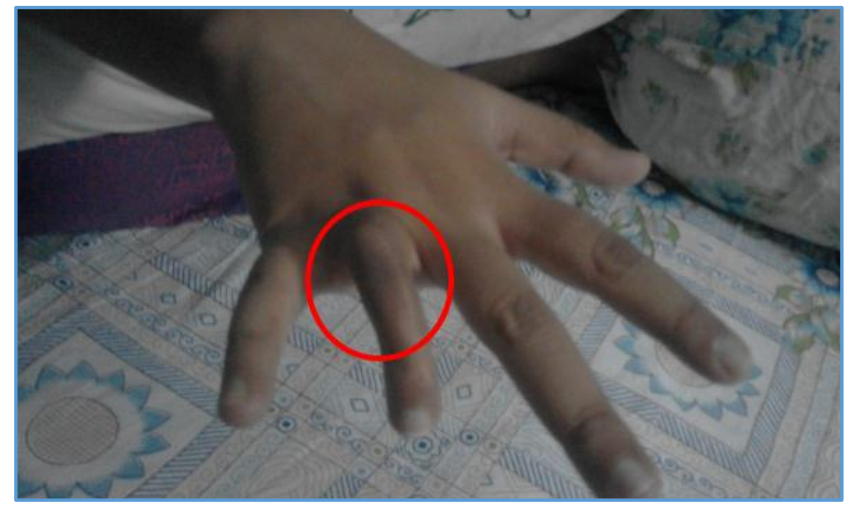

Figure 8. Photograph of right hand shows the right ring finger after amputation of middle phalanx followed by iliac bone grafting and arthrodesis

\section{DISCUSSION}

GCT of hand, especially of phalanx is extremely rare and it appears different from conventional GCT seen in other sites of skeleton. ${ }^{4}$ In this case, the first radiological diagnosis was aneurysmal bone cyst, the commonest differential diagnosis of GCT. GCT of phalanx is so rare that in a series of 108 cases of GCT, only two cases were reported. ${ }^{4,10}$ In a larger series of 2400 skeletal GCTs reported in literature, less than 50 were arising from phalanx. 4,11,12 In another two large series of 568 and 327 of GCT, only 4 and 1 reported as phalangeal involvement respectively. ${ }^{11}$

The treatment modalities of GCT of hand included aggressive curettage, cancellous bone grafting, wide excision along with structural bone grafting, amputation and ray amputation. $4,7,8,9,13$ However, high recurrence (90\%) rate have been reported even with these treatment procedures.4,7,8,9,14 Considering total number of GCT of all locations, high local recurrence rate has also been observed in few series ranging from 30.7 to $88.0 \% .^{1,2,3}$ Distance metastasis is extremely rare. In few cases, involvement of lung and lymph node was reported.1,2 It is observed that most of the local recurrences of GCT in hand are reported to occur within one year of initial surgery. ${ }^{4,8}$ In our case also, local recurrence occurred after 10 months of primary surgery with bone grafting. But after excision of affected middle phalanx of right ring finger followed by iliac bone grafting and arthrodesis of PIP and DIP joints, she has been found disease free for last six years.

In one of the largest series of GCT of hand, reported by Averill et al ${ }^{6}$, comprising of 28 lesions (14 in Phalanges) in 21 patients, 16 of the cases had local recurrence.4,6 Two of six cases of finger phalangeal involvement of GCT, reported in the series by Goldenberg et al 15 developed local recurrence. In our case, the patient was comfortable with a cosmetically improved right ring finger. [Figure 8].
Due to comparative rarity of GCT originating from middle phalanx of finger, the present case was planned for reporting.

\section{CONCLUSION}

Though GCT in phalanx is an extremely rare location, it should always be kept in mind during clinical and radiological evaluation because GCTs originating from small bone of hand (e.g. Phalanx or metacarpals) are highly aggressive tumours with significant incidence of recurrence.

\section{REFERENCES}

1. Roy S, Mukherjee S, Mahata M, et al. Giant cell tumour in first metacarpal bone: a rare entity. International Journal of Medical Science and Public Health 2016;5(5):1049-51.

2. Dhilon MS, Prasad P. Multicentric giant cell tumour of bone. Acta Orthop Belg 2007;73(3):289-99.

3. Witting JC, Simpson BM, Bickels J, et al. Giant cell tumour of the hand: superior result with curettage cryosurgery and cementation. J Hand Surg [Br] 2001;26(3):546-55.

4. Saikia KC, Bhuyan SK, Goswami S, et al. Rare site giant cell tumour: report of two cases on phalanges of the finger and review of literature. J Orthop Traumatol 2009;10(4):193-7.

5. Eckardt JJ, Grogan TJ. Giant cell tumour of bone. Clin Orthop 1986;204:45-58.

6. Averill RM, Smitt RJ, Campell CJ. Giant cell tumour of bone of the hand. J Hand Surg 1980;5:39-50.

7. Wold LE, Swee RG. Giant cell tumours of small bone of hands and feet. Semin Diang Pathol 1984;1(3):173-84.

8. Athanasian EA, Wold LE, Amadio PC. Giant cell tumour of bones of the hand. J Hand Surg 1997;221(1):91-8.

9. Patel MR, Desai SS, Gardon SL et al. Management of skeletal giant cell tumour of the phalanges of the hand. J Hand Surg 1987;12 A:70-7.

10. Coley BL, Higisibotham NL, Koguse T. Giant cell tumour of bone. Am J Surg 1958;96:479-91.

11. Unni KK. Dahlin's bone tumours: general aspects and data on 11087 cases. $5^{\text {th }}$ edn. Philadelphia, PA: LippincottRaven 1996:263-83.

12. Campanacci $M$, Baldini N, Boriani $S$, et al. Giant cell tumours of bone. J Bone Joint Surgery 1987;69(1):106-14.

13. Minha MS, Mehboob G, Ansari J. Giant cell tumour of hand bones. J Col Physician Surg Pak 2010;20(7):460-3.

14. Slesarencko YA, Sampson SP, Gould ES. Giant cell tumour of distal phalanx of the hand. Hand Surg 2005;10(23):289-91.

15. Goldeberg RR, Campbell CJ, Bofiglio M. Giant-cell tumour of bone: an analysis of 218 cases. J Bone Joint Surg 1970;52(4):619-64. 